\title{
EFFICACY OF CERTAIN CHEMICAL AND SAFE ALTERNATIVE COMPOUNDS ON THE CABBAGE APHID BREVICORYNE BRASSICAE (LINNAEUS) AND ITS ASSOCIATED PARASITOID DIAERETIELLA RAPAE (MCLNTOCH) INHABITING CABBAGE PLANTATIONS
}

\author{
Farouk A. Abdel-Galil *, Safaa, M.A. Amro**, Abd El-Raheem A. Abd El -Raheem** \\ and Dalya Y.A. Darwish* \\ *Plant Protection Department, Faculty of Agriculture, Assiut University, Assiut, Egypt. \\ ** Plant Protection Research Institute, Agricultural Research Center, Dokki, Giza, Egypt. \\ Corresponding Author, Email address: faagalil@hotmail.com
}

\section{ABSTRACT:}

The study was conducted to evaluate the efficacy of two newly introduced European safe alternative compounds (Evure ${ }^{\circledR}$ and Karate ${ }^{\circledR}$ Zeon) versus two biocide compounds (Biosad $22 \%$ SC and Abamectin 1.8\% EC), and the chemical compound (Melody 24\% SC) against the cabbage aphid Brevicoryne brassicae (Linnaeus) inhabiting cabbage plantations during 2017/18 and 2018/19 cabbage growing seasons in Assiut, northern upper Egypt. Impact of the tested compounds on the infestation levels and the yield income was evaluated. Also, their side effect against the emergence of the aphid parasitoid Diaeretiella rapae (Mclntoch) was taken in consideration. Data revealed that the newly introduced compound (Karate® Zeon) was the most effective compound on the population density of $B$. brassicae during the entire period of study with $98.98 \%$ reduction in the pest numbers. The other newly introduced compound (Evure ${ }^{\circledR}$ ) reduced the pest numbers by less reduction percentage $(94.20 \%)$, and ranked the second. The chemical compound (Melody $24 \% \mathrm{SC}$ ) reduced the pest populations by $93.40 \%$ (less than both of the two newly introduced safe alternative compounds). The biocide compounds (Abamectin 1.8\% EC and Biosad 22\% SC) presented 78.99 and $59.08 \%$ reduction in the pest populations and appeared as the least effective compounds. Efficacy on the infestation levels and damaged (unmarketable) plants showed slight variation between the tested compounds (ranged between 47.46 -55.34 and 46.78-49.10\%, respectively). So, use of these compounds led to an increase in the marketable cabbage plants (yield income) by more than $50 \%$. Unfortunately the highest effective compound (Karate ${ }^{\circledR}$ Zeon) against cabbage aphid reduced the emerged parasitoid D. rapae by 91.64\%, and consequently could be has cautions as aphids control agent. According to their acceptable effectiveness against $B$. brassicae populations, infestation levels , unmarketable plants and low effectiveness against $\mathrm{D}$. rapae, it can be recommended to use the biocide compounds (Abamectin 1.8\% EC and Biosad 22\% SC) to manage the population density of cabbage aphids in the field by more than one application throughout one season.

Key words: Cabbage aphid, parasitoids, chemical control, safe alternative compounds. 


\section{INTRODUCTION}

The cabbage aphid Brevicoryne brassicae (Linnaeus) causes serious losses of yield in Brassica crops and reduces its marketable value (Liu et al., 1994; Costello and Altieri, 1995). This insect pest is one of the most common pests of cabbage crop in Egypt (El-Fakharany and Hendawy, 2010). Aphid's associated parasitoids are very important control agents in a variety of agricultural and horticultural crops. The hymenopterous parasitoid Diaeretiella rapae (McIntosh) is a highly polyphagous parasitic wasp parasitizing exclusively aphids throughout the world infesting hundreds of plant species, both cultivated and wild (Singh and Singh, 2015). Several decades ago, D. rapae was reported as the most effective natural enemy against the cabbage aphid, B. brassicae (George,1957) and it has been observed to cause as high as $\mathbf{7 2 \%}$ parasitism in the Netherlands (Hafez, 1961) and $76 \%$ parasitism in Kenya (Bahana and Karuhize,1986). Continuous usage of broad-spectrum insecticides for aphid control was an occasion to its resurgence, secondary pest outbreaks, and increasing levels of resistance to insecticides. So, predominant pest control strategy has led to intensification of research on alternative control techniques and to the use of selective insecticides. Among the products that are recommended for aphid control, Pymetrozine has reported highest selectivity, systematic insecticide that harmless to natural enemies and can be used in integrated pest management (IPM) programs (Rimaz and Valizadegan, 2013). Spinosyns compounds being of biological origin, and are considered to have a low environmental impact and they are not much aggressive against non-target species. Also, these compounds had broad range of action against many insect pests belonging to different orders, noxious to a wide variety of agricultural crops. For all these reasons, these compounds are considered one of the most interesting products to be used in fighting against agricultural pests (Bacci et al., 2016). Bio-pesticides such as abamectin has been reported as broad-spectrum pesticides with high biological activity with dosage as low as 1-3 g active ingredient per hectare. With such a low rate, such pesticides not only provide protection to the environment but also are safe to human beings (UNIDO, 2008). Therefore, this work has been conducted to evaluate the efficacy of certain chemical and safe alternative compounds such as Bio-pesticides in reducing the cabbage aphid, B. brassicae populations in the field. Also, their potency to reduce the infestation levels and yield loss (unmarketable plants) has been evaluated. The side effect of these compounds on the aphid parasitoid D. rapae was also taken in consideration.

\section{MATERIALS AND METHODS}

The present investigations were conducted at the Experimental Farm of Assiut University during 2017-2018 and 2018-2019 cabbage growing seasons by using Ganzory cabbage cultivar at (Ca.1/4 fed.) and divided into plots (1/400 fed. / plot). Plants were transplanted in $50 \mathrm{~cm}$ intervals at 3rd October during both seasons. Insecticides application was initiated as aphid populations reached to moderate density (two months post transplantation). To evaluate the reduction 
percentage of $B$. brassicae (all forms), 4 cabbage leaves were randomly picked up from 4 cabbage plants (1 leaf / plant) / each replicate (4 replicates) in addition to the control replicates and transferred to the laboratory to later examination. Mean numbers of $B$. brassicae (all forms) were counted / 5 inches / leaf, before spray by the selected compounds (Table 1) and consequently after 3, 7 and 14 days post application. Reduction percentage of the targeted insect pest numbers, were calculated according to Henderson and Tilton (1955) equation. Reduction percentage of the infested and unmarketable plants (Figure 1), were also calculated in the field. One hundred mummified aphids were isolated in test tubes ( 4 replicates / each compound and the control replicate) before spray and after 3,7 and 14 days post application. Reduction percentage of the emerged parasitoid (D. rapae), were calculated according to the same equation. Data were statistically analyzed by using F-test and means were compared according to Duncan's multiple range tests as described by Steel and Torrie (1982).

Table1. Trade name, common name and application rate of the tested compounds against $B$. brassicae and its parasitoid D. rapae.

\begin{tabular}{||c|c|c|}
\hline \hline Trade name & Common name & Application rate \\
\hline Evure $\AA$ & Tau-fluvalinate $21,4 \%(240 \mathrm{~g} / \mathrm{l})$ & $10 \mathrm{ml} / 100$ Litter water \\
\hline Karate ${ }^{\circledR}$ Zeon & Lambda cyhalothrin $\mathrm{Sc} 9.4 \%$ & $31.2 \mathrm{ml} / 100$ Litter water \\
\hline Biosad $22 \% \mathrm{SC}$ & Spinosad & $10 \mathrm{ml} / 100$ Litter water \\
\hline Abamectin $1.8 \% E C$ & Bermectin & $40 \mathrm{ml} / 100$ Litter water \\
\hline Melody $24 \% \mathrm{SC}$ & Metoxyfenozide & $25 \mathrm{ml} / 100$ Litter water \\
\hline
\end{tabular}

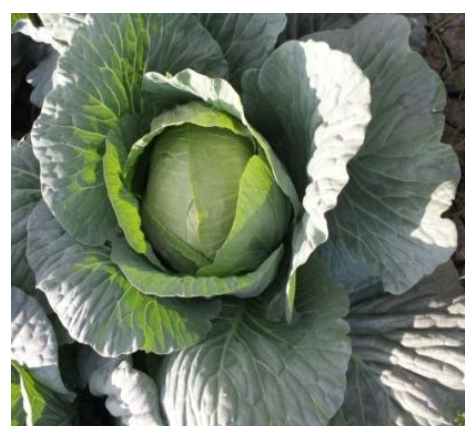

A

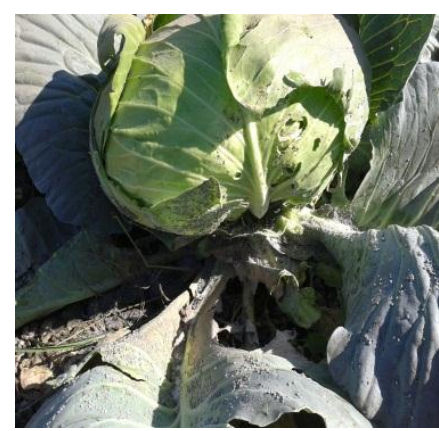

B

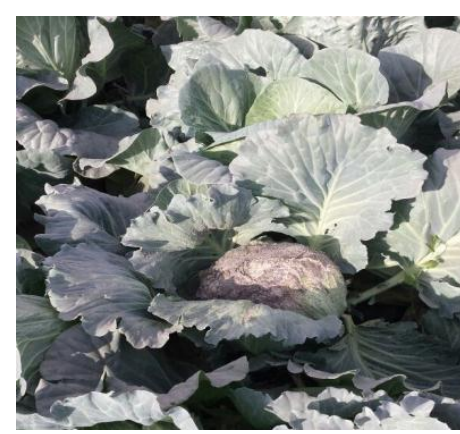

C

Figure1. Cabbage aphid Brevicoryne brassicae damage symptoms on cabbage plants (A: Healthy plant, B: Infested plant, C: Unmarketable plant)

\section{RESULTS AND DISCUSSION Effectiveness of two newly} introduced European safe alternative compounds (Evure ${ }^{\circledR}$ and Karate ${ }^{\circledR}$ Zeon) versus two biocide compounds (Biosad 22\% SC and Abamectin 1.8\%EC), and the chemical compound (Melody 24\%SC) were evaluated in the field against the cabbage aphid B. brassicae inhabiting cabbage plantations during 2017-2018 and 2018-2019 growing seasons in Assiut governorate, northern Upper Egypt. Impact of the tested compounds on the infestation levels and the yield income was evaluated. Also, their side effect against the emergence of the aphid parasitoid D. rapae was taken in consideration. The obtained results in Table (2) revealed that the newly introduced compound (Karate $®$ Zeon) was the most effective compound on the population density of $B$. brassicae during the first season of study with $99.53 \%$ reduction in 
the pest numbers throughout 14 days post application. The other newly introduced compound (Evure®) reduced the pest numbers by less reduction percentage $(93.47 \%)$, and ranked the second. The chemical compound (Melody 24\%SC) ranked the third and reduced the pest numbers by $92.80 \%$ (Less than both of the two newly introduced safe alternative compounds). The least effective compounds against this insect pest were the biocide compounds (Abamectin $1.8 \% \quad$ EC and Biosad $22 \%$ SC) which reduced the pest numbers by $\mathbf{7 8 . 2 0}$ and $\mathbf{5 5 . 3 5 \%}$, respectively. Highly significant variations $(f=41.068 * *)$ were recorded between the tested compounds. Data presented in Table (3) showed the effectiveness of the tested compounds to reduce the pest infestation levels. Variation between the most effective compound (Karate ${ }^{\circledR}$ Zeon) and the least effective one (Biosad $22 \%$ SC) was not high (ranged between $\mathbf{5 0 . 3 3}$ and 43.08\%).Consequently non-significant variations $(f=1.495)$ were recorded between the tested compounds. Effectiveness of the tested compounds on the damaged (unmarketable) plants (Table 4) showed similar trend with non-significant variations $(f=0.092)$.

Side effect of the tested compounds on the emergence percentage of the aphid parasitoid D. rapae was presented in Table (5). Karate ${ }^{\circledR}$ Zeon was the most effective compound against the parasitoid and ranked the first with $(91.47 \%)$ reduction. The remaining compounds efficacy can be arranged as descending as follows: Melody 24\%SC by $50.35>$ Evure $\AA$ by $42.89>$ Abamectin 1.8\% EC by 19.63> Biosad 22\%
SC by $10.22 \%$. Highly significant variations (f $=173.703 * *)$ were recorded between the tested compounds. With few exceptions, similar results (Tables 6-9) were obtained during the second season of study.

Data presented in Table (10) and illustrated in Figure (2) expressed about the mean reduction percentages on all of the tested measurements during both experimental seasons. Data revealed that, the newly introduced compound (Karate $\AA$ Zeon) was the most effective compound on the population density of $B$. brassicae during the entire period of study with $\mathbf{9 8 . 9 8 \%}$ reduction in the pest numbers. It followed by the other newly introduced safe alternative compound (Evure ${ }^{\circledR}$ ) with average reduction $94.20 \%$.The chemical compound (Melody $24 \%$ SC) reduced the pest populations by $93.40 \%$. However, the biocide compounds (Abamectin 1.8\% EC and Biosad $22 \% \mathrm{SC}$ ) reduced the pest populations by $\mathbf{7 8 . 9 9}$ and $\mathbf{5 9 . 0 8 \%}$ and appeared as the least effective compounds. Effectiveness on the infestation levels and damaged (unmarketable) plants showed slight variation between the tested compounds (ranged between $47.46 \quad-55.34$ and 46.78-49.10\%, for the above-mentioned measurements, respectively). In general, potency of the tested compounds to reduce the pest populations was highly synchronized with their potency to reduce the pest infestation levels. Also, use of these compounds increased the marketable cabbage plants (yield income) by more than $50 \%$. Unfortunately, the side effect of the most effective compounds (Karate ${ }^{\circledR}$ Zeon) against B. brassicae was so high against its parasitoid D. rapae. It reduced its 
emergence by $91.64 \%$. On the other hand, moderately reduction percentages on the emerged parasitoid numbers were obtained by using both of (Melody $24 \% \mathrm{SC}$ and Evure ${ }^{\circledR)}$ by 53.40 and $46.27 \%$, respectively. The least effective compounds against $D$. rapae emergence (Abamectin 1.8\% EC and Biosad 22\% SC) showed 23.76 and $12.01 \%$ reduction, respectively.

In general it can be note that, the highest effective compound (Karate $®$ Zeon) against $B$. brassicae populations can reduce the effectiveness of the aphid parasitoid $D$. rapae by $91.64 \%$. So, its application could have cautions as aphids control agent. The remaining compounds showed moderately effect on the emerged parasitoid numbers. According to their acceptable effectiveness against $B$. brassicae populations, infestation levels, unmarketable plants and low effectiveness against $D$. rapae, it can be recommended to use the biocide compounds (Abamectin 1.8\% EC and Biosad 22\% SC) to manage the population density of cabbage aphids in the field by more than one application during the cabbage growing season.

Successful use of Abamectin (Bermectine) $1.8 \% \mathrm{EC}$ at $40 \mathrm{ml} / \mathbf{1 0 0 L}$ water against the cabbage aphid $B$. brassicae in the field was applied in Northern Egypt by El-Fakharany and Hendawy (2010). They reported that, this compound reduced $B$. brassicae populations by 91.54 and $92.08 \%$ during 2008/09 and 2009/10 cabbage growing seasons, respectively. Also, they reported that, this compound had slight effects on the aphid's associated natural enemies (Predators, true spiders and parasitoids). Efficacy of Abamectin against various stages of the red palm weevil Rhynchophorus ferrugineus (Olivier) (Coleoptera: Curculionidae) under laboratory conditions was evaluated in Saudi Arabia by (Albutairi et al., 2016). Their bioassay test showed that, Abamectin at $600 \mathrm{ppm}(\mu \mathrm{g} / \mathrm{ml})$ caused $60 \%$ mortality against females and males after 24 h. By increasing the concentration to $1000 \mathrm{ppm}$, the mortality reached $100 \%$ for adults. In other applications by some derivatives of the tested products, (Amro and Abdel-Galil, 2012) used Radiant $12 \%$ SC (Spinotoram) in the same area of study and reduced onion thrips, Thrips tabaci Lindeman infesting onion heads by $89.75 \%$. On the other hand, El-Wakeil and Volkmar (2013) proved that Karate caused the highest percent mortality to wheat insect pests and reduced natural enemy diversities. However, Salem et al. (2018) reported that, Karate and Tracer 24\% SC (Spinosad) reduced cereal aphid complex infesting wheat by 99.31 and $\mathbf{9 7 . 0 5 \%}$, respectively.

\section{ACKNOWLEDGEMENT}

The authors were grateful to Prof. Dr. Abdellah Said Hussein Abdel-Moniem, Head of Plant Protection Department, Faculty of Agricultural, Beni-Suef University, for supplying with the newly used safe alternative compounds. Especial thank to the staff members of Plant Protection Department, Faculty of Agriculture, Assiut University and staff members of Insect Research Laboratory in Assiut, Plant Protection Research Institute for supporting and encouragement during the study. 


\section{REFERENCES}

Albutairi, A.; Laden, N. G. and Al

Saud, Y.H. 2016. Efficacy of Abamectin (ABM) against various stages of $R$. ferrugineus under laboratory conditions. Advances in Agric. and Agric. Sci., 2 (6): 108-116.

Amro, M. A. and Abdel-Galil, F. A. 2012. Can safe alternative compounds used as a promising tool for suppressing Thrips tabaci (Lind.) inhabiting onion seed plantations? The 6rd. Int. Conf. for Develop. and the Env. in the Arab world, March, 24-26:167-175.

Bacci, L.; Lupi, D.; Savoldelli, S. and Rossaro, B. 2016. A review of Spinosyns, a derivative of biological acting substances as a class of insecticides with a broad range of action against many insect pests. J. Entomol. and Acarol. Res., 48: 4052.

Bahana, J. and Karuhize, G. 1986. The role of Diaeretiella rapae (McIntosh) (Hym: Braconidae) in the population control of the cabbage aphid, Brevicoryne brassicae L. (Hem.: Aphididae) in Kenya. Ins. Sci. Appl., 7: 605-609.

Costello, M. J. and Altieri, M. A. 1995. Abundance, growth rate and parasitism of Brevicoryne brassicae and Myzus persicae (Homoptera: Aphididae) on broccoli grown in living mulches. Agric., Ecosystems and Environment, 52: 187-196.

El-Wakeil, N. and Volkmar, C. 2013. Monitoring of wheat insects and their natural enemies using sticky traps in wheat. Arch. Phytopathol. and Plant. Protect. 46(13-16): 1523-1532.

George, K.S.1957. Preliminary investigations on the biology and ecology of the parasites and predators of Brevicoryne brassicae (L.), Bull. Entomol. Res., 48: 619629.

El-Fakharany, S.M. and Hendawy, A. S. 2010. Effects of climatic factors and toxic compounds on aphids and their natural enemies in cabbage fields. Bull. ent. Soc. Egypt, Econ. Ser., 36:249-269.

Hafez, M. 1961. Seasonal fluctuations in population density of the cabbage aphid Brevicoryne brassicae (L.) in the Netherlands, and the role of its parasite Aphidius (Diaeretiella) rapae (Curtis). Tijdsch. Pl.-ziekten, Nederlands, 67:445448.

Henderson, C.F. and Tilton, E.W. 1955. Tests with acaricides against the brown wheat mite. J. Econ. Entomol., 48: 157-161.

Liu, S. S.; Hommes, M. and Hildenhagen, R. 1994. Damage to white cabbage by the aphid Brevicoryne brassicae (L.): influence of aphid density and stage of plant growth. IOBC / WPRS Bull., 17: 7589.

Rimaz, V. and Valizadegan, $O$. 2013. Toxicity of agricultural adjuvant cytogate oil and the insecticide pymetrozine to the cabbage aphid, Brevicoryne brassicae L. (Hemiptera: Aphididae) and its parasitoid, Diaeretiella rapae $M$. (Hymenoptera: Aphidiidae). Egypt. J. Biol. Pest Cont., 23(2):221-225.

Salem, A. A.; Amro, M. A.; AbdelMoniem, A. S. H. and Abdel-Galil, Y. M. A. 2018. Determination the population trends of cereal aphids and associated parasitoids by yellow sticky traps with reference to aphid management on wheat. Arch. 
Phytopathol. and Plant. Protect. 50(1920):1034-1042.

Singh, R. and Singh, G. 2015. Systematics, distribution and host range of Diaeretiella Rapae (McIntosh) (Hymenoptera: Braconidae, Aphidiinae) . Int. J. of Res. Studies in Biosciences (IJRSB)., 3 (1): 1-36

Steel, R.G.D. and Torrie, J.H. 1982.

Principals and procedures of statistics. A biometrical approach, McGraw-Hill Book Co.

UNIDO, 2008.Workshop on production and application of bio-pesticides (abamectin, emmamectin and natural pyrethrum), Nantong, People's Republic of China, October 14-16, p. 70. http://internationalscholarsjournals.org/do wnload.php. 
Table2. Potency of the tested compounds in reducing numbers of cabbage aphids Brevicoryne brassicae infesting cabbage plants during 2017-2018 cabbage growing season in Assiut region

\begin{tabular}{|c|c|c|c|c|c|c|c|c|c|}
\hline \multirow{3}{*}{ Compound } & \multicolumn{7}{|c|}{$\begin{array}{l}\text { Mean numbers of } B \text {. brssicae / } 4 \text { leaves ( } 5 \text { inches } 2 \text { / leaf) / plot } \\
\text { and reduction } \%\end{array}$} & \multirow{3}{*}{ GR\% } & \multirow{3}{*}{ RO } \\
\hline & \multirow{2}{*}{$\begin{array}{l}\text { Before } \\
\text { spraying }\end{array}$} & \multicolumn{2}{|c|}{ After 3 days } & \multicolumn{2}{|c|}{ After 7 days } & \multicolumn{2}{|c|}{ After 14 days } & & \\
\hline & & MN & $\mathbf{R} \%$ & MN & $\mathbf{R \%}$ & $\mathbf{M N}$ & $\mathbf{R \%}$ & & \\
\hline Evure ${ }^{\circledR}$ & 865.0 & 148.8 & 87.76 & 50.00 & 96.34 & 31.0 & 96.32 & 93.47B & 2 \\
\hline Karate® Zeon & 882.5 & 3.50 & 99.71 & 5.00 & 99.63 & 7.50 & 99.26 & 99.53A & 1 \\
\hline Biosad $22 \%$ SC & 873.8 & 440.0 & 64.00 & 457.0 & 68.28 & 625.0 & 33.76 & 55.35D & 5 \\
\hline Abamectin $1.8 \% \mathrm{EC}$ & 882.5 & 370.0 & 69.76 & 286.3 & 80.48 & 150.0 & 84.36 & 78.20C & 4 \\
\hline Melody 24\%SC & 886.3 & 91.25 & 92.80 & 62.50 & 95.76 & 96.25 & 89.88 & 92.80B & 3 \\
\hline Control & 872.5 & 1220 & ----- & 1437.5 & ---- & 943.8 & ----- & ----- & \\
\hline
\end{tabular}

MN = Mean numbers, R\% = Reduction \%, GR\% = General Reduction \%, $\mathbf{R O}=$ Ranking order F value between treatments $=41.068 * *$

Table3. Potency of the tested compounds in reducing percentages of the infested cabbage plants by cabbage aphids Brevicoryne brassicae during 2017-2018 cabbage growing season in Assiut region

\begin{tabular}{|c|c|c|c|c|c|c|c|c|c|}
\hline \multirow{3}{*}{ Compound } & \multicolumn{7}{|c|}{$\begin{array}{l}\text { Mean percentage of the infested cabbage plants / plot } \\
\text { and reduction \% }\end{array}$} & \multirow{3}{*}{ GR\% } & \multirow{3}{*}{ RO } \\
\hline & \multirow{2}{*}{$\begin{array}{c}\text { Before } \\
\text { spraying }\end{array}$} & \multicolumn{2}{|c|}{ After 3 days } & \multicolumn{2}{|c|}{ After 7 days } & \multicolumn{2}{|c|}{ After 14 days } & & \\
\hline & & MP & $\mathbf{R} \%$ & MP & $\mathbf{R} \%$ & MP & $\mathbf{R} \%$ & & \\
\hline Evure ® & 6.00 & 6.00 & 38.00 & 6.00 & 53.00 & 6.25 & 58.40 & 49.80A & 2 \\
\hline Karate $®$ Zeon & 5.00 & 5.00 & 38.00 & 5.00 & 53.00 & 5.00 & 60.00 & 50.33A & 1 \\
\hline Biosad 22\% SC & 4.00 & 4.00 & 38.00 & 5.00 & 41.25 & 5.00 & 50.00 & 43.08C & 5 \\
\hline Abamectin $1.8 \% \mathrm{EC}$ & 5.00 & 5.00 & 38.00 & 5.75 & 45.95 & 6.25 & 50.00 & $44.65 \mathrm{C}$ & 4 \\
\hline Melody $24 \%$ SC & 7.00 & 7.00 & 38.00 & 8.00 & 46.42 & 8.00 & 54.40 & 46.27B & 3 \\
\hline Control & 8.00 & 13.00 & ----- & 17.00 & ---- & 20.00 & ---- & ---- & \\
\hline
\end{tabular}

MP = Mean percentage, $\mathbf{R} \%=$ Reduction \%, GR\% = General Reduction \%, RO = Ranking order F value between treatments $=\mathbf{1 . 4 9 5}$

Table4. Potency of the tested compounds in reducing percentages of the unmarketable cabbage plants infested by cabbage aphid Brevicoryne brassicae during 2017 -2018 cabbage growing season in Assiut region.

\begin{tabular}{|c|c|c|c|c|c|c|c|c|c|}
\hline \multirow{3}{*}{ Compound } & \multicolumn{7}{|c|}{$\begin{array}{c}\text { Mean percentage of the unmarketable cabbage plants / plot } \\
\text { and reduction \% }\end{array}$} & \multirow{3}{*}{ GR\% } & \multirow{3}{*}{ RO } \\
\hline & \multirow{2}{*}{$\begin{array}{l}\text { Before } \\
\text { spraying }\end{array}$} & \multicolumn{2}{|c|}{ After 3 days } & \multicolumn{2}{|c|}{ After 7 days } & \multicolumn{2}{|c|}{ After 14 days } & & \\
\hline & & MP & $\mathbf{R} \%$ & MP & $\mathbf{R} \%$ & MP & $\mathbf{R} \%$ & & \\
\hline Evure ${ }^{\circledR}$ & 5.00 & 5.00 & 29.00 & 5.50 & 58.20 & 8.00 & 55.20 & 47.47A & 2 \\
\hline Karate $₫$ Zeon & 5.00 & 5.00 & 29.00 & 7.00 & 46.80 & 7.50 & 58.00 & 44.60C & 5 \\
\hline Biosad 22\% SC & 5.00 & 5.50 & 21.90 & 6.25 & $\mathbf{5 2 . 5 0}$ & 6.25 & 65.00 & 46.47B & 3 \\
\hline Abamectin 1.8\% EC & 4.00 & 4.00 & 29.00 & 5.00 & 52.50 & 6.50 & 54.36 & 45.29B & 4 \\
\hline Melody 24\%SC & 6.00 & 6.00 & 29.00 & 7.00 & 55.92 & 9.00 & 58.00 & 47.64A & 1 \\
\hline Control & 5.00 & 7.00 & ----- & 13.00 & ---- & 18.00 & $-\cdots$ & +--- & \\
\hline
\end{tabular}

MP $=$ Mean percentage, $\mathbf{R} \%=$ Reduction \%, GR\% = General Reduction $\%, \mathbf{R O}=$ Ranking order F value between treatments $=0.092$ 
Table5. Potency of the tested compounds in reducing percentages of the aphid emerged parasitoid (Diaeretiella rapae) inhabiting cabbage during 2017 -2018 cabbage growing season in Assiut region

\begin{tabular}{|c|c|c|c|c|c|c|c|c|c|}
\hline \multirow{3}{*}{ Compound } & \multicolumn{7}{|c|}{$\begin{array}{c}\text { Mean percentage of emerged parasitoids / } 100 \text { mummified aphid } \\
\text { and reduction \% }\end{array}$} & \multirow{3}{*}{ GR\% } & \multirow{3}{*}{ RO } \\
\hline & \multirow{2}{*}{$\begin{array}{c}\text { Before } \\
\text { spraying }\end{array}$} & \multicolumn{2}{|c|}{ After 3 days } & \multicolumn{2}{|c|}{ After 7 days } & \multicolumn{2}{|c|}{ After 14 days } & & \\
\hline & & MP & $\mathbf{R} \%$ & MP & $\mathbf{R} \%$ & MP & $\mathbf{R} \%$ & & \\
\hline Evure $®$ & 88.75 & 38.25 & 57.43 & 54.75 & 34.28 & $\mathbf{5 5 . 5 0}$ & 36.37 & 42.69C & 3 \\
\hline Karate $®$ Zeon & 86.25 & 5.25 & 94.06 & 7.50 & 90.46 & 8.50 & 89.90 & 91.47A & 1 \\
\hline Biosad $22 \%$ SC & 88.75 & 75.50 & 15.85 & 77.75 & 6.72 & 80.75 & 8.09 & $10.22 \mathrm{E}$ & 5 \\
\hline $\begin{array}{l}\text { Abamectin } \\
1.8 \% \text { EC }\end{array}$ & 83.75 & 57.00 & 32.68 & 69.05 & 13.08 & 71.75 & 13.14 & 19.63D & 4 \\
\hline Melody $24 \%$ SC & 90.50 & 43.50 & 52.48 & 43.75 & 49.12 & 45.50 & 49.50 & 50.36B & 2 \\
\hline Control & 90.75 & 92.00 & ----- & 85.50 & ----. & 89.50 & ----- & ----- & \\
\hline
\end{tabular}

MP = Mean percentage, R\% = Reduction \%, GR\% = General Reduction \%, RO = Ranking order F value between treatments $=173.703 * *$

Table6. Potency of the tested compounds in reducing numbers of cabbage aphids Brevicoryne brassicae infesting cabbage plants during 2018-2019 cabbage growing season in Assiut region

\begin{tabular}{|c|c|c|c|c|c|c|c|c|c|}
\hline \multirow{3}{*}{ Compound } & \multicolumn{7}{|c|}{$\begin{array}{l}\text { Mean numbers of B. brssicae / } 4 \text { leaves (5 inches2 / leaf) / plot } \\
\text { and reduction \% }\end{array}$} & \multirow{3}{*}{ GR\% } & \multirow{3}{*}{ RO } \\
\hline & \multirow{2}{*}{$\begin{array}{c}\text { Before } \\
\text { spraying }\end{array}$} & \multicolumn{2}{|c|}{ After 3 days } & \multicolumn{2}{|c|}{ After 7 days } & \multicolumn{2}{|c|}{ After 14 days } & & \\
\hline & & MN & $\mathbf{R} \%$ & $\mathbf{M N}$ & $\mathbf{R} \%$ & $\mathbf{M N}$ & $\mathbf{R} \%$ & & \\
\hline Evure ® & 795.5 & 80.00 & 93.30 & 63.50 & 95.12 & 42.25 & 96.35 & 94.92B & 2 \\
\hline Karate® Zeon & 805.5 & 15.50 & 98.66 & 18.55 & 98.78 & 20.50 & 97.81 & $98.42 \mathrm{~A}$ & 1 \\
\hline Biosad 22\% SC & 855.0 & 480.5 & 62.48 & 395.5 & 71.94 & 535.25 & 54.01 & 62.81D & 5 \\
\hline $\begin{array}{c}\text { Abamectin } \\
1.8 \% \mathrm{EC}\end{array}$ & 799.5 & 320.0 & 73.20 & 270.5 & 79.26 & 145.5 & 86.86 & 79.77C & 4 \\
\hline Melody 24\%SC & 840.5 & 85.50 & 93.30 & 73.50 & 94.51 & 70.00 & 94.16 & 93.99B & 3 \\
\hline $\begin{array}{l}\text { Control } \\
\end{array}$ & 835.0 & 1250 & $-\cdots$ & 1360 & $-\cdots$ & 1150 & ------ & ------ & \\
\hline
\end{tabular}

MN = Mean numbers, R\% = Reduction \%, GR\% = General Reduction \%, RO = Ranking order F value between treatments $=73.206 * *$

Table7. Potency of the tested compounds in reducing percentages of the infested cabbage plants by cabbage aphids Brevicoryne brassicae during 2018-2019 cabbage growing season in Assiut region

\begin{tabular}{|c|c|c|c|c|c|c|c|c|c|}
\hline \multirow{3}{*}{ Compound } & \multicolumn{7}{|c|}{$\begin{array}{l}\text { Mean percentage of the infested cabbage plants / plot } \\
\text { and reduction } \%\end{array}$} & \multirow{3}{*}{ GR\% } & \multirow{3}{*}{ RO } \\
\hline & \multirow{2}{*}{$\begin{array}{c}\text { Before } \\
\text { spraying }\end{array}$} & \multicolumn{2}{|c|}{ After 3 days } & \multicolumn{2}{|c|}{ After 7 days } & \multicolumn{2}{|c|}{ After 14 days } & & \\
\hline & & MP & R\% & MP & $\mathbf{R} \%$ & MP & $\mathbf{R} \%$ & & \\
\hline Evure ${ }^{\circledR}$ & 5.50 & 5.50 & 50.00 & 5.50 & 61.00 & 6.25 & 68.08 & 59.69A & 2 \\
\hline Karate $®$ Zeon & 6.50 & 6.50 & 50.00 & 6.50 & 61.00 & 7.00 & 70.04 & 60.35A & 1 \\
\hline Biosad $22 \%$ SC & 6.00 & 7.00 & 41.50 & 7.50 & 51.25 & 8.00 & 62.76 & $51.84 \mathrm{C}$ & 5 \\
\hline Abamectin $1.8 \%$ EC & 5.50 & 6.00 & 45.50 & 6.25 & 55.54 & 6.50 & 66.96 & $56.00 B$ & 4 \\
\hline Melody $24 \%$ SC & 6.00 & 6.00 & 50.00 & 6.00 & 61.00 & 7.00 & 67.24 & $59.41 \mathrm{~A}$ & 3 \\
\hline Control & 6.00 & 12.0 & ---- & 15.50 & $-\cdots$ & 21.50 & ----- & ----- & \\
\hline
\end{tabular}

MP = Mean percentage, $\mathbf{R} \%=$ Reduction \%, GR\% = General Reduction \%, RO = Ranking order F value between treatments $=\mathbf{1 . 5 8 7}$ 
Table8. Potency of the tested compounds in reducing percentages of the unmarketable cabbage plants infested by cabbage aphid Brevicoryne brassicae during 2018 -2019 cabbage growing season in Assiut region.

\begin{tabular}{|c|c|c|c|c|c|c|c|c|c|}
\hline \multirow{3}{*}{ Compound } & \multicolumn{7}{|c|}{$\begin{array}{l}\text { Mean percentage of the unmarketable cabbage plants / plot } \\
\text { and reduction } \%\end{array}$} & \multirow{3}{*}{ GR\% } & \multirow{3}{*}{ RO } \\
\hline & \multirow{2}{*}{$\begin{array}{c}\text { Before } \\
\text { spraying }\end{array}$} & \multicolumn{2}{|c|}{ After 3 days } & \multicolumn{2}{|c|}{ After 7 days } & \multicolumn{2}{|c|}{ After 14 days } & & \\
\hline & & MP & $\mathbf{R} \%$ & MP & $\mathbf{R} \%$ & MP & $\mathbf{R} \%$ & & \\
\hline Evure ® & 6.50 & 6.50 & 25.00 & 6.75 & 55.28 & 6.75 & 71.92 & 50.73A & 2 \\
\hline Karate $®$ Zeon & 6.25 & 6.25 & 25.00 & 6.25 & 57.00 & 6.50 & 71.92 & 51.31A & 1 \\
\hline Biosad $22 \%$ SC & 5.75 & 6.00 & 22.00 & 6.00 & 55.28 & 6.25 & 70.57 & 49.21B & 4 \\
\hline Abamectin $1.8 \%$ EC & 4.75 & 5.00 & 21.25 & 5.00 & 54.85 & 5.50 & 68.68 & 48.26B & 5 \\
\hline Melody $24 \%$ SC & 5.00 & 5.00 & 25.00 & 5.25 & 54.85 & 5.50 & 70.30 & 50.05A & 3 \\
\hline Control & 6.00 & 8.00 & ---- & 14.00 & ---- & 22.50 & ---- & ----- & \\
\hline
\end{tabular}

$\mathrm{MP}=$ Mean percentage, $\mathrm{R} \%=$ Reduction \%, GR\% $=$ General Reduction \%, $\mathbf{R O}=$ Ranking order $F$ value between treatments $=0.039$

Table9. Potency of the tested compounds in reducing percentages of the aphid emerged parasitoid (Diaeretiella rapae) inhabiting cabbage during 2018 -2019 cabbage growing season in Assiut region

\begin{tabular}{|c|c|c|c|c|c|c|c|c|c|}
\hline \multirow{3}{*}{ Compound } & \multicolumn{7}{|c|}{$\begin{array}{c}\text { Mean percentage of emerged parasitoids } / 100 \text { mummified aphid } \\
\text { and reduction } \%\end{array}$} & \multirow{3}{*}{ GR\% } & \multirow{3}{*}{ RO } \\
\hline & \multirow{2}{*}{$\begin{array}{c}\text { Before } \\
\text { spraying }\end{array}$} & \multicolumn{2}{|c|}{ After 3 days } & \multicolumn{2}{|c|}{ After 7 days } & \multicolumn{2}{|c|}{ After 14 days } & & \\
\hline & & MP & $\mathbf{R} \%$ & MP & $\mathbf{R} \%$ & MP & $\mathbf{R} \%$ & & \\
\hline Evure ${ }^{\circledR}$ & 87.50 & 37.50 & 57.86 & 52.50 & 41.20 & 43.50 & 50.50 & 49.85C & 3 \\
\hline Karate $₫$ Zeon & 86.50 & 6.50 & 92.16 & 7.00 & 92.16 & 7.50 & 91.09 & $91.80 \mathrm{~A}$ & 1 \\
\hline Biosad $22 \%$ SC & 88.25 & 80.00 & 10.52 & 76.50 & 14.74 & 75.25 & 15.85 & $13.80 \mathrm{E}$ & 5 \\
\hline $\begin{array}{c}\text { Abamectin } \\
1.8 \% \mathrm{EC}\end{array}$ & 82.50 & 62.50 & 25.52 & 60.25 & 28.46 & 58.50 & 29.71 & 27.89D & 4 \\
\hline Melody $24 \%$ SC & 88.50 & 42.50 & 52.96 & 40.25 & 55.90 & 39.50 & 55.45 & 56.44B & 2 \\
\hline Control & 89.50 & 91.50 & ---- & 91.00 & - ---- & 90.25 & ----- & -----. & \\
\hline
\end{tabular}

MP = Mean percentage, $\mathbf{R} \%=$ Reduction \%, GR\% $=$ General Reduction \%, RO = Ranking order $F$ value between treatments $=370.711 * *$

Table10. Potency of the tested compounds in reducing Brevicoryne brassicae populations, percent infestation, unmarketable cabbage plants and merged parasitoids \% during 2017-2018 and 2018-2019 cabbage growing seasons in Assiut region.

\begin{tabular}{|c|c|c|c|c|c|c|c|c|}
\hline \multirow{3}{*}{ Compound } & \multicolumn{8}{|c|}{$\begin{array}{c}\text { General reduction percentage during 2017-2018 and } 20182019 \\
\text { cabbage growing seasons }\end{array}$} \\
\hline & \multicolumn{2}{|c|}{$\begin{array}{l}\text { B. brassicae } \\
\text { Populations }\end{array}$} & \multicolumn{2}{|c|}{ Infested plants $\%$} & \multicolumn{2}{|c|}{$\begin{array}{l}\text { Unmarketable } \\
\text { plants \% }\end{array}$} & \multicolumn{2}{|c|}{$\begin{array}{c}\text { Emerged } \\
\text { parasitoids \% }\end{array}$} \\
\hline & $\mathbf{R} \%$ & RO & $\mathbf{R} \%$ & RO & $\mathbf{R} \%$ & RO & $\mathbf{R} \%$ & RO \\
\hline Evure $®$ & 94.20 & 2 & 54.75 & 2 & 49.10 & 1 & 46.27 & 3 \\
\hline Karate $₫$ Zeon & 98.98 & 1 & 55.34 & 1 & 47.96 & 3 & 91.64 & 1 \\
\hline Biosad $22 \%$ SC & 59.08 & 5 & 47.46 & 5 & 47.88 & 4 & 12.01 & 5 \\
\hline Abamectin $1.8 \%$ EC & 78.99 & 4 & 50.33 & 4 & 46.78 & 5 & 23.76 & 4 \\
\hline Melody $24 \%$ SC & 93.40 & 3 & 52.84 & 3 & 48.85 & 2 & 53.40 & 2 \\
\hline
\end{tabular}

$\mathrm{R} \%=$ Reduction \%, RO = Ranking Order 


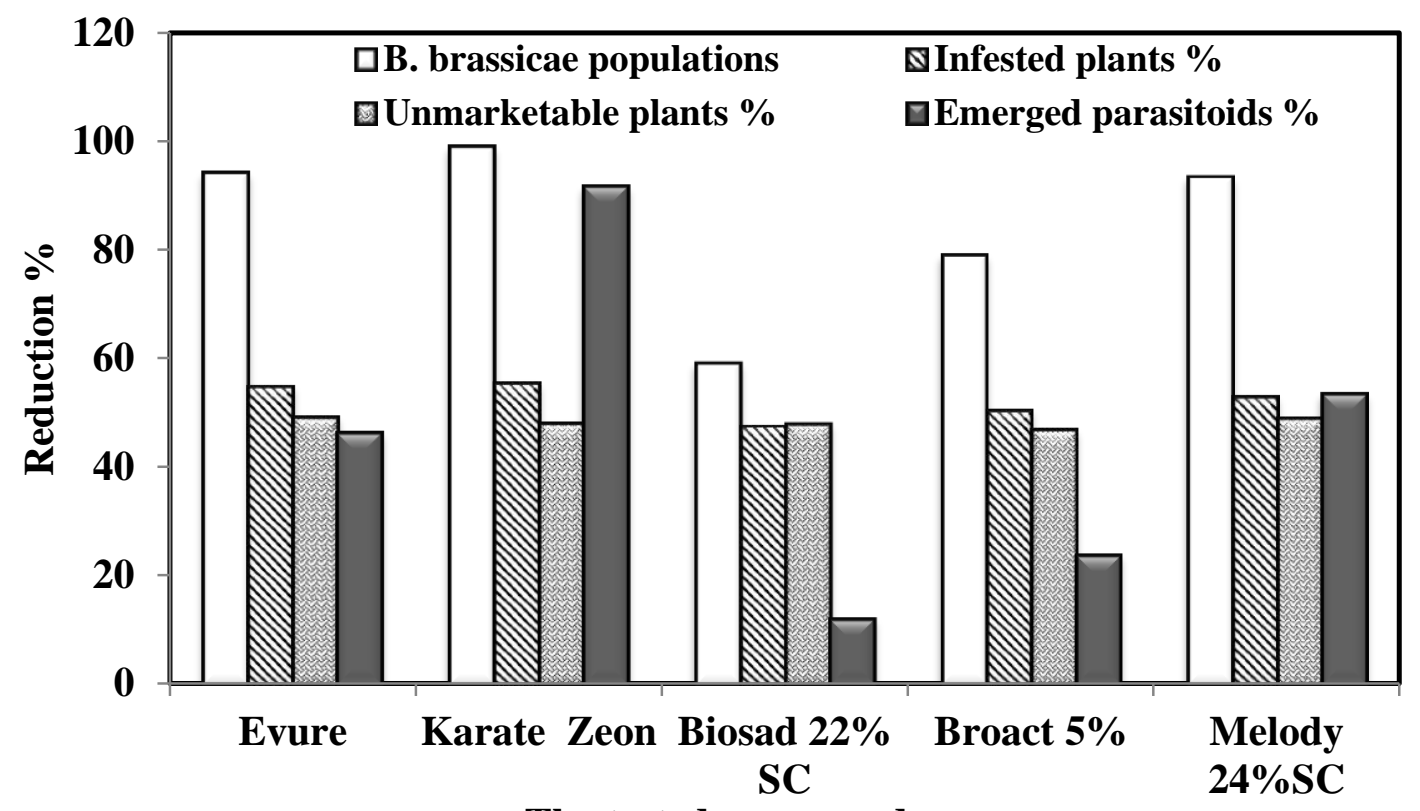

Figure 2. Potency of the tested compounds in reducing Brevicoryne brassicae populations, percent infestation, unmarketable cabbage plants and merged parasitoids \% during 2017-2018 and 2018-2019 cabbage growing seasons in Assiut region. 


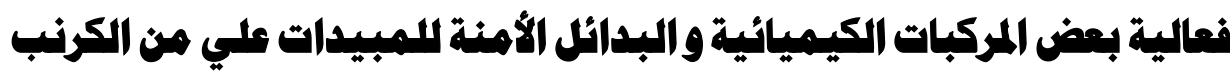

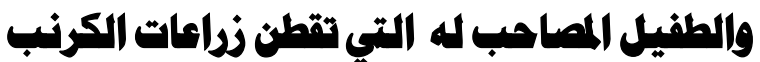

فاروق عبد القوى عبد الجليل* , صفاء محمد عبدالرحمن عمرو** ,عبد الرحيم أحمد عبد الرحيم** , وداليا يوسف عوض درويش* * قسم وقاية النبات - كلية الزراعة - جامعة أسيوط. ** معهد بحوث وقاية النباتات - مركز البحوث الزراعية - الدقى - الجيزة - مصر .

Evure® and Karate® ( أجريت الدراسة لتقييم فعالية مركبين حليثي الأستيراد من الأتحاد الأوربي

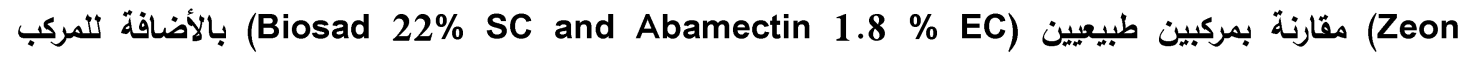

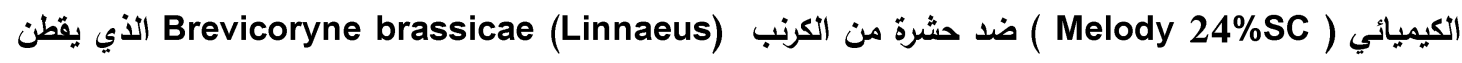

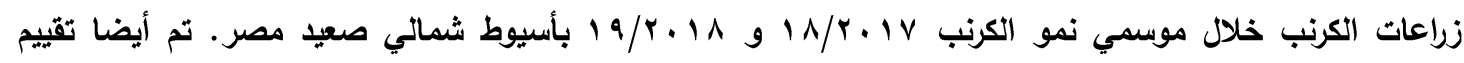

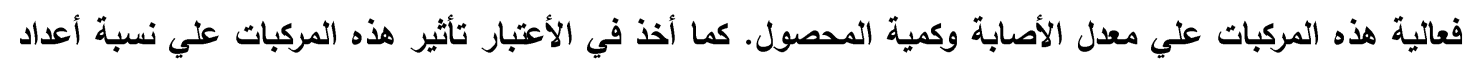

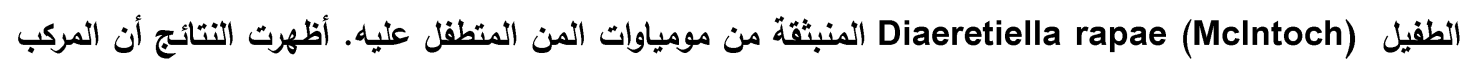
(Karate® Zeon)

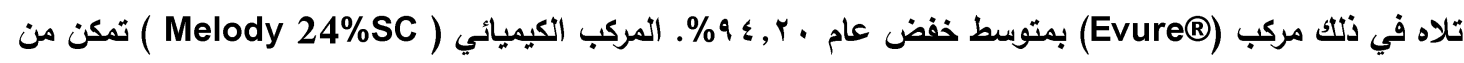

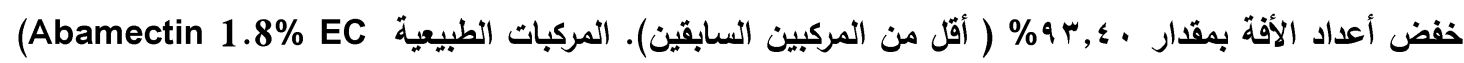
أظهرت أقل نسبة خفض في تعداد الأفة بمقار 9 and Biosad 22\% SC)

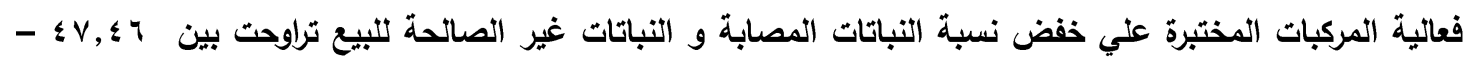

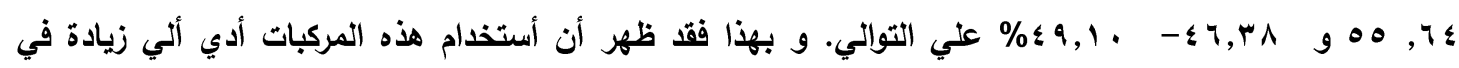

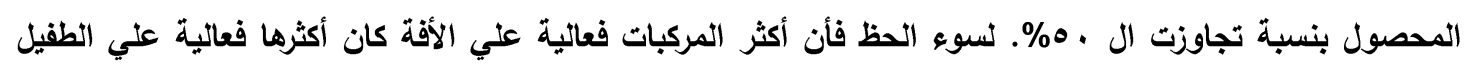

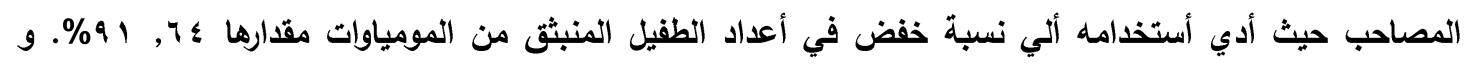

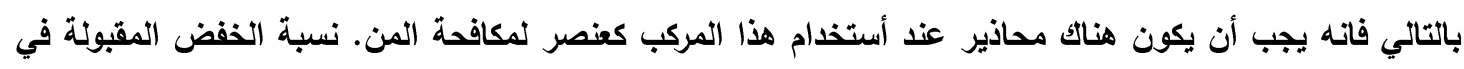

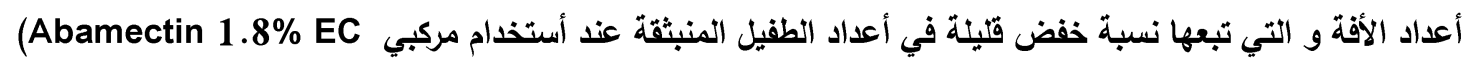

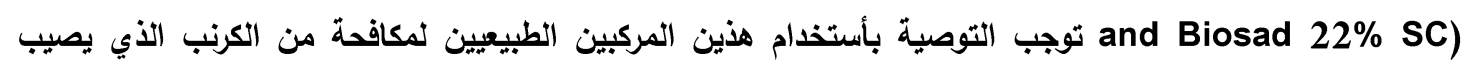
الكرنب حتي لو أستدعي ذلكك تطبيقها أكثر من مرة في الموسم الواحد. الكامات الدالة : الكرنب ومن الصليبيات والثفيلات وإثكافحة الكيميائية وإثبائل الأمنة للمبيدات. 